\title{
MEDIA PEMBELAJARAN $E$-LEARNING DALAM PEMBELAJARAN PENDIDIKAN AGAMA ISLAM DI SMA LABORATORIUM PERCONTOHAN UPI BANDUNG
}

\author{
Rijki Ramdani*, Munawar Rahmat, Agus Fakhruddin \\ Universitas Pendidikan Indonesia \\ *Email: rijkiramdani@gmail.com
}

\begin{abstract}
The Internet can be used as a way to transfer knowledge from teacher to student. Elearning is one of learning media which uses internet. The purpose of this research is to describe and analyze: (1) the learning planning; (2) the learning process; (3) the learning evaluation; (4) the learning process results of Islamic Education learning with e-learning. This research uses qualitative approach and descriptive method. The data collection technique are interviens, observation, and study of documentation. This research was conducted in SMA Laboratorium Percontohan UPI Bandung who have used e-learning as a learning media. Based on the results of the research, it was found that the learning planning of Islamic Education learning with e-learning is not much different with no use of e-learning. The learning implementation process of Islamic Education learning with e-learning is conducted by the method of lecture that assisted with e-learning as a students learning resource centre. Learning evaluation of Islamic Education learning with e-learning is done in the moment after the sub chapter materials have been studied by students with automated systems in e-learning. The results of the learning process of Islamic Education learning with e-learning effect on student learning outcomes. The influence is only experienced on the competence of knowledge, while attitude and skills there is no correlation.
\end{abstract}

Keyword: E-learning, Learning Media, Islamic Education learning

\begin{abstract}
ABSTRAK
Internet dapat dijadikan cara untuk transfer pengetahuan dari guru kepada siswa. Pembelajaran yang memanfaatkean internet salah satunya adalab media pembelajaran e-learning. Tujuan penelitian ini untuk mendeskripsikan dan menganalisis: (1) perencanaan pembelajaran; (2) proses pembelajaran; (3) evaluasi pembelajaran; (4) basil proses pembelajaran PAI dengan elearning. Penelitian ini menggunakan pendekatan kualitatif dan metode deskriptif. Teknik. pengumpulan data dilakukan dengan cara wawancara, observasi dan studi dokumentasi. Penelitian ini dilakukan di SMA Laboratorium Percontohan UPI Bandung yang telah menggunakan media pembelajaran e-learning. Berdasarkan basil penelitian, ditemukan babwa perencanaan pembelajaran PAI dengan e-learning tidak jauh berbeda dengan tidak menggunakan e-learning. Proses pelaksanaan pembelajaran PAI dengan e-learning dilakukan dengan metode ceramah yang dibantu dengan media pembelajaran e-learning sebagai pusat sumber belajar siswa. Evaluasi pembelajaran PAI dengan e-learning dilakukan pada saat setelah sub bab materi telah dipelajari oleh siswa dengan sistem otomatis pada e-learning. Hasil proses pembelajaran PAI dengan elearning berpengarub terbadap hasil belajar siswa. Pengaruh tersebut banya dialami pada kompetensi pengetahuan saja, sedangkan sikap dan keterampilan tidak ada korelasinya.
\end{abstract}

Kata Kunci : E-learning, Media Pembelajaran, Pendidikan Agama Islam 


\section{PENDAHULUAN}

Pada dasarnya proses belajar mengajar adalah proses komunikasi. Komunikasi belajar mengajar di kelas merupakan kegiatan komunikasi tersendiri di mana guru dan siswa saling bertukar pikiran dengan tujuan mengembangkan ide dan pengertian. Penyimpangan-penyimpangan komunikasi sering timbul dan terjadi pada saat kegiatan proses belajar mengajar sehingga akan terjadi komunikasi yang tidak efektif dan efisien antara lain disebabkan oleh adanya kecenderungan guru yang belum mampu menciptakan media pembelajaran yang efektif dan adanya kecenderungan siswa yang kurang siap. Salah satu usaha untuk mengatasi keadaan adalah penggunaan media secara terintegrasi dalam proses belajar mengajar, karena fungsi media dalam kegiatan tersebut di samping sebagai penyaji stimulus informasi dan sikap juga untuk meningkatkan keserasian dalam penerimaan informasi.

Dalam dunia pendidikan, internet dapat dijadikan sebuah pembelajaran. pembelajran ini berupa electronic learning atau yang lebih dikenal dengan istilah $e$ learning. Munadi (2010, hal. 159) mengemukakan e-learningdapat diartikan sebagai jenis bahan belajar mengajar yang memungkinkan tersampaikannya bahan ajar ke siswa dengan menggunakan media internet atau media jaringan komputer lain.

Secara ideal guru PAI harus mampu menggunakan dan memanfaatkan media pembelajaran $e-$ learning yang telah disediakan oleh sekolah sesuai dengan kebutuhan siswa agar materi PAI yang disampaikan dapat diserap baik oleh siswa dan tujuan pembelajaran dapat tercapai secara optimal, sehingga siswa akan terpenuhi kompetensinya, baik pengetahuan, sikap maupun keterampilan dalam mengikuti mata pelajaran PAI. Dengan terpenuhinya kompetensi tersebut, kualitas sekolah akan meningkat.

Dalam proses pembelajaran PAI di sekolah, penggunaan e-learning sebagai media pembelajaran masih jarang ditemukan. Hal ini dikarenakan sekolah belum dapat memfasilitasi media pembelajaran e-learning tersebut. Selain itu, masih banyak guru yang belum mampu menggunakan dan memanfaatkan teknologi dan informasi secara maksimal yang telah disediakan oleh sekolah untuk dikembangkan sebagai media pembelajaran dalam hal ini e-learning.

Berdasarkan sebab-sebab dan beberapa permasalahan di atas, maka peneliti tertarik untuk melihat penggunakan media pembelajaran $E$ learning dalam pembelajaran Pendidikan Agama Islam (PAI) di SMA Laboratorium Percontohan UPI Bandung.

\section{METODE PENELITIAN}

Pendekatan yang penulis gunakan dalam penelitian ini adalah kualitatif yakni bermaksud untuk memahami fenomena tentang apa yang dialami oleh subjek penelitian (Moleong, 2012, hal. 6). Pada penelitian ini, peneliti menggunakan metode deskriptif. Menurut Nazir (1999, hal. 63) metode deskriptif adalah suatu metode dalam meneliti status sekelompok manusia, suatu objek, suatu kondisi, suatu sistem 
pemikiran ataupun suatu kelas peristiwa pada masa sekarang. Tujuan dari penelitan deskriptif ini adalah untuk membuat deskripsi gambaran atau lukisan secara sistematis, faktual, dan akurat mengenai fakta-fakta, sifatsifat serta hubungan antar fenomena yang diselidiki.

Teknik pengumpulan data yang peneliti gunakan di antaranya wawancara, observasi dan studi dokumentasi. Adapun tahapan analisis data yang dilakukan penelitian adalah dengan mereduksi data dengan memilih data yang dibutuhkan serta dikategorikan dengan koding. Data hasil reduksi disajikan dalam display data dengan uraian singkat secara deskriptif dan kemudian disimpulkan.

\section{HASIL DAN PEMBAHASAN}

\section{Perencanaan Pembelajaran PAI dengan e-learning}

Model pembelajaran berbasis teknologi informasi dengan menggunakan e-learning berakibat pada perubahan budaya belajar dalam kontek pembelajarannya. Menurut Rohmah (2016, hal. 15) setidaknya ada empat komponen penting dalam membangun budaya belajar dengan menggunakan model e-learningdi sekolah, keempat komponen itu ialah (1) Peserta didik dituntut secara mandiri dalam belajar dengan berbagai pendekatan yang sesuai agar siswa mampu mengarahkan, memotivasi, mengatur dirinya sendiri dalam pembelajaran. (2) Pendidik mampu mengembangkan pengetahuan dan keterampilan, memfasilitasi dalam pembelajaran, memahami belajar dan hal-hal yang dibutuhkan dalam pembelajaran. (3) Tersedianya infrastruktur yang memadai (4) Adanya administrator yang kreatif serta penyiapan infrastrukur dalam memfasilitasi pembelajaran.

Pembelajaran yang efektif terus diupayakan oleh SMA Laboratorium Percontohan UPI. Menurut Sagala (2006, hal. 61) bahwa pembelajaran ialah membelajarkan siswa menggunakan asas pendidikan maupun teori belajar merupakan penentu utama keberhasilan pendidikan, pembelajaran merupakan proses komunikasi dua arah, mengajar dilakukan oleh pihak guru sebagai pendidik, sedangkan belajar dilakukan oleh peserta didik atau murid. Pernyataan di atas menunjukkan bahwa pada hakikatnya proses belajar mengajar adalah proses komunikasi. Komunikasi belajar mengajar di kelas merupakan suatu dunia komunikasi tersendiri dimana guru dan siswa bertukar pikiran untuk mengembangkan ide dan pengertian. Untuk mewujudkan komunikasi yang efektif maka SMA Laboratorium Percontohan UPI membangun sistem pembelajaran e-learning. e-learning adalah media pembelajaran, suatu media pembelajaran menurut Munadi (2010, hal. 36) harus mempunyai fungsi yaitu (1) media pembelajaran berfungsi sebagai sumber belajar (2) fungsi semantik dan (3) fungsi manipulatik. Kedua analisis fungsi yang didasarkan pada penggunanya (anak didik) terdapat dua fungsi yakni (4) fungsi psikologis dan (5) fungsi sosio-kultural. Maka teori tersebut menjadi pertimbangan sekolah dalam membangun e-learning. 


\section{Rijki Ramdani, Munawar Rahmat, Agus Fakhruddin}

SMA Laboratorium Percontohan UPI beranggapan bahwa e-learning dapat dikatakan sebagai media pembelajaran yang fleksibel dan mempermudah proses pembelajaran. Hal ini sejalan dengan teori manfaat e-learning menurut Rohmah (2016, hal. 12), yaitu (1) dengan adanya e-learning maka dapat mempersingkat waktu pembelajaran dan membuat biaya studi lebih ekonomis (2) E-learning mempermudah interaksi antara peserta didik dengan bahan materi, (3) Peserta didik dapat saling berbagi informasi dan dapat mengakses bahan-bahan belajar setiap saat dan berulang-ulang, dengan kondisi yang demikian itu peserta didik dapat lebih memantapkan penguasaannya terhadap materi pembelajaran (4) Dengan e-learning proses pengembangan pengetahuan tidak hanya terjadi di dalam ruangan kelas saja, tetapi dengan bantuan peralatan komputer dan jaringan, para siswa dapat secara aktif dilibatkan dalam proses belajar-mengajar.

Media pembelajaran e-learning di SMA Laboratorium Percontohan UPI sudah menjadi kebijakan sekolah hanya saja e-learning belum diwajibkan oleh guru untuk diterapkan hanya sebatas menganjurkan. Hal tersebut karena kendala pada kualitas SDM yaitu guru yang seluruhnya belum bisa menyesuaikan teknologi. Hal tersebut disayangkan terhadap profesionalisme guru yang belum dipenuhi oleh sebagian guru. Menurut Kusnandar (2011, hal. 46)bahwa guru profesional adalah guru yang senantiasa menguasai bahan atau materi pelajaran yang akan diajarkan dalam interkasi belajar mengajar yang disesuaikan dengan perkembangan zaman, serta senantiasa mengembangkan kemampuannya secara berkelanjutan, baik dalam segi ilmu yang dimilikinya maupun pengalamannya. Namun guru PAI di SMA Laboratorium Percontohan UPI, beliau menggunakan media pembelajaran e-learning, maka dari itu, guru PAI di SMA Laboratorium Percontohan UPI dapat dikategorikan sebagai guru yang profesional.

$\begin{array}{ccr}\text { Selain } & \text { itu, perencanaan } \\ \text { pembelajaran } & \text { PAI pada media } \\ \text { pembelajaran } & \text { e-learning, perlu adanya } \\ \text { pernyusunan } & \text { perangkat ajar. }\end{array}$
Penyusunan perangkat ajar bertujuan untuk memenuhi proses pembelajaran. Proses komunikasi yang dapat dikatakan sebagai proses pembelajaran harus memenuhi tiga ciri pembelajaran yaitu (1) Rencana, ialah penataan ketenagaan, material, dan prosedur yang merupakan unsur-unsur sistem pembelajaran, dalam suatu rencana khusus. (2) Kesalingtergantungan, antara unsur-unsur sistem pembelajaran yang serasi dalam suatu keseluruhan. Tiap unsur bersifat esensial, dan masing-masing memberikan sumbangannya kepada sistem pembelajaran. (3) Tujuan, sistem pembelajaran mempunyai tujuan tertentu yang hendak dicapai. (Hamalik, 2010). Tidak menuntut kemungkinan pada media pembelajaran e-learning juga harus memenuhi tiga ciri di atas, karena e-learning adalah salah satu alat pada proses pembelajaran.

Rencana pembelajaran menjadi hal yang harus diakukan oleh setiap guru. Guru di SMA Laboratorium Percontohan UPI merencanakan pembelajaran pada perangkat ajar 
silabus dan RPP. Baik itu ketika menggunakan media pembelajaran elearning maupun tidak. Penyusunan program tahunan, program semester, Silabus, RPP, bahan ajar, strategi pembelajaran, alokasi waktu, tujuan pembelajaran, materi pembelajaran dan sebagainya tidak begitu berbeda dengan tidak menggunakan media pembelajaran e-learning. Tetapi jika menggunakan media pembelajaran elearning harus memperhatikan strategi penggunaan e-learning. Strategi penggunaan e-learning seperti disampaikan Effendi (2005, hal. 18) berguna untuk (1) memperjelas tujuan pelatihan atau pendidikan yang ingin dicapai (2) mengetahui sumber daya yang dibutuhkan (3) membuat semua pihak yang terlibat untuk tetap mengacu pada tujuan yang sama. (4) mengetahui pengukuran keberhasilan. Strategi pembelajaran e-learning akan mengarahkan guru terhadap ruang lingkup pembelajaran, dimana pembelajaran efektif akan terjadi.

Menurut Hartanto (2016, hal. 20) bahwa sistem dan aplikasi e-learning yang sering disebut dengan Learning Management System (LMS), yang merupakan sistem perangkat lunak yang memvirtualisasi proses belajar mengajar konvensional untuk administrasi, dokumentasi, laporan suatu program pelatihan, ruangan kelas dan peristiwa online, program e-learning, dan konten pelatihan, misalnya, segala fitur yang berhubungan dengan manajemen proses belajar mengajar seperti bagaimana manajemen kelas, pembuatan materi atau konten, forum diskusi, sistem penilaian, serta sistem ujian online yang semuanya terakses dengan internet. Perencanaan tersebut harus dipenuhi oleh guru SMA Laboratorium Percontohan UPI untuk melengkapi fitur yang terdapat dalam $e$ learning tersebut. Dan pada akhirnya guru PAI sudah menyiapkan komponen yang akan dicantumkan dalam media pembelajaran e-learning tersebut.

\section{Proses Pelaksanaan \\ Pembelajaran PAI dengan e- learning}

Pembelajaran PAI dengan menggunakan media pembelajaran elearning di SMA Laboratorium Percontohan UPI dilakukan secara campuran yang sebagian besar proses pembelajarannya menggunakan $e$ learning. Namun terkadang dilakukan secara keseluruhan menggunakan elearning, hal itu dilakukan pada saat guru tidak bisa masuk ke kelas. Hal ini sejalan dengan teori yang disebutkan oleh Eli Rohaeti dalam Rokhman, dkk. (2015, hal. 56) bahwa proses pembelajaran secara e-learning dapat diselenggarakan dalam berbagai cara berikut (1) Proses pembelajaran secara konvensional (lebih banyak face to face meeting) dengan tambahan pembelajaran melalui media interaktif komputer melalui internet atau menggunakan grafik interaktif komputer. (2) Dengan metode campuran, yakni sebagian besar proses pembelajaran dilakukan melalui komputer, namun tetap juga memerlukan face to face meeting untuk kepentingan tutorial atau mendiskusikan bahan ajar. (3) Metode pembelajaran yang secara keseluruhan hanya dilakukan secara online, metode ini sama sekali tidak ditemukan face to face meeting. 


\section{Rijki Ramdani, Munawar Rahmat, Agus Fakhruddin}

Metode diatas menunjukkan bahwa media pembelajaran e-learning bukan sebagai pengganti pembelajaran konvensional, melainkan sebagai alat bantu pembelajaran. Karena Menurut Hartanto (2016, hal. 28) pembelajaran yang memanfaatkan Learning Management System Efront sebagai medianya merupakan pembelajaran yang berpusat pada peserta didik. Dalam pembelajaran ini guru berperan sebagai fasilitator dan guru bukan merupakan satu-satunya sumber belajar. Peserta didik dapat saling berdiskusi dan bertukar informasi dari sumber yang ada. Dalam pembelajaran ini, Learning Management System Efront dapat dikatakan sebagai VLE singkatan dari Virtual Learning Environment atau lingkungan belajar maya. Dalam pelaksanaannya, pembelajaran PAI dengan menggunakan e-learning di SMA Laboratorium Percontohan UPI seringkali guru menjelaskan di depan kelas, kemudian siswa memperhatikan dan memahami materi yang terdapat dalam e-learning. Hal yang dilakukan oleh guru PAI di SMA Laboratorium Percotnohan UPI adalah benar, siswa perlu adanya arahan pembelajaran bukan semata-mata siswa dilepaskan untuk belajar mandiri, meskipun pembelajaran tersebut menggunakan strategi student centre learning.

Kemudian, pembelajaran PAI dapat dilakukan tanpa kehadiran guru, apabila guru tersebut berhalangan hadir. Masalah tersebut dapat diatasi dengan media pembelajaran e-learning. sistem e-learning akan menghitung lamanya belajar siswa awal sampai akhir. Hal tersebut selaras dengan yang dikatakan oleh Hartanto (2016, hal. 28) bahwa peserta didik dapat belajar selayaknya dikelas nyata pada saat pembelajaran konvensional, selain itu Learning Management System Efront juga berperan sebagai media berbagi, berdiskusi, dan belajar bersama dengan memanfaatkan berbagai fitur dan fasilitas pendukung yang ada. Di SMA Laboratorium Percontohan UPI sering terjadi demikian, terutama pada semester 2 yang kerap banyak kegiatan di luar sekolah yang berakibat guru tidak bisa hadir ke kelas. Tetapi ada kendala dengan sistem pembelajaran seperti itu, diantaranya guru tidak bisa secara langsung mengamati siswa ketika proses pembelajaran, ini adalah kelemahan besar terhadap pembelajaran PAI yang semestinya menjunjung nilai-nilai akhlak.

Learning

Management

SystemEfrontsebagaipusatsumber belajar mempunyai tujuan dan fungsi tersendiri. Tujuan secara umum menurutMudhoffir dalam Hamid (2015, hal. 63) bahwa pusatsumberbelajarbertujuanmeningkat kan efektifitas dan efisiensi kegiatan proses belajar-mengajar melalui pengembangan sistem instruksional. Di SMA Laboratorium Percontohan UPI pada pembelajaran PAI dengan media pembelajaran e-learning seringkali $e$ learning menjadi pusat sumber belajar. Guru PAI meencantumkan materi pembelajaran PAI pada e-learning. Materi pembelajaran PAI yang dicantumkan adalah materi yang sudah di komparasikan dari berbagai sumber yakni internet, buku dan multimedia. Maka dari itu, e-learning sebagai pusat sumber belajar akan mngefektifkan siswa dalam memahami materi yang 
tidak perlu lagi siswa untuk mengkomparasikan. Dengan demikian peneliti sepakat bahwa Learning Management System Efront yang digunakan di SMA Laboratorium Percontohan UPI sebagai pusat sumber belajar mempunyai peranan yang cukup menentukan di dalam meningkatkan efektifitas dan efisiensi proses pembelajaran.

Bentuk konten yang dicantumkan dalam media pembelajaran e-learning di SMA Laboratorium Percontohan UPI oleh guru PAI adalah konten teks. Tetapi terkadang mutimedia berupa video kadang digunakan. Hal tersebut sejalan dengan teori yang digagas oleh Hartanto (2016, hal. 21) bahwa konten dan bahan ajar ini bisa dalam bentuk misalnya Multimedia-based Content atau konten berbentuk multimedia interaktif seperti multimedia pembelajaran yang memungkinkan kita menggunakan mouse, keyboard untuk mengoperasikannya atau Text-based Content yaitu konten berbentuk teks seperti pada buku pelajaran yang ada di wikipedia.org, ilmukomputer.com, dsb. Biasa disimpan dalam Learning Management System (LMS) sehingga dapat dijalankan oleh peserta didik kapan pun dan dimana pun. Tetapi, yang terjadi di lapangan bahwa pada konten pembelajaran PAI masih terkendala terhadap dukungan penulisan arab.

Konten-konten tersebut wajib dirampungkan oleh siswa sebagai syarat ketuntasan dalam proses pembelajaran. Menurut Permendikbud Nomor 104 tahun 2014 tentang Penilaian Hasil Belajar pada Jenjang Dikdasmen bahwa Ketuntasan Belajar adalah tingkat minimal pencapaian kompetensi sikap, pengetahuan, dan keterampilan meliputi ketuntasan penguasaan substansi dan ketuntasan belajar dalam konteks kurun waktu belajar. Ketuntasan Belajar terdiri atas ketuntasan penguasaan substansi dan ketuntasan belajar dalam konteks kurun waktu belajar. Ketuntasan penguasaan substansi yaitu ketuntasan belajar KD yang merupakan tingkat penguasaan peserta didik atas $\mathrm{KD}$ tertentu pada tingkat penguasaan minimal atau di atasnya, sedangkan ketuntasan belajar dalam konteks kurun waktu belajar terdiri atas ketuntasan dalam setiap semester, setiap tahun ajaran, dan tingkat satuan pendidikan. Dalam pelaksanaan pembelajaran PAI di SMA Laboratorium Percontohan UPI ketika menggunakan media pembelajaran elearing bahwa ketuntasan pembelajaran dibuktikan dengan hasil nilai evaluasi pada setiap sub konten yang ada. Setiap sub konten di cantumkan pertanyaan yang wajib dijawab secara benar oleh siswa, tujuannya adalah untuk menuntaskan pembelajaran pada sub itu dan siswa dapat melanjutkan sub konten lainnya. Dengan demikian, dapat dikatakan bahwa peneliti sepakat terhadap pelaksanaan pembelajaran PAI ketika menggunakan media pembelajaran e-learning terhadap yang dilakukan oleh guru PAI di SMA Laboratorium Percontohan UPI.

Dalam realitas pendidikan yang terjadi di Indonesia terutama di sekolah, e-learning tidak bisa meniadakan unsur hubungan pedagogis antara guru dan siswa. Karena bilamana ini terjadi, dikhawatirkan proses pembelajaran menjadi kehilangan makna esensialnya 


\section{Rijki Ramdani, Munawar Rahmat, Agus Fakhruddin}

yang mencakup berbagai dimensi baik kognitif, afektif dan psikomotorik (Rohmah, 2016, hal. 15). Hal tersebut sejalan dengan yang terjadi di lapangan. SMA Laboratorium Percontohan UPI tidak sepenuhnya mengandalkan $e$ learning sebagai pembelajaran. Guru tidak mampu melihat perkembangan sikap dan keterampilan siswa dalam proses pembelajaran. Dalam pembelajaran PAI yang syarat dengan pendidikan nilai, maka tidak mungkin dilaksanakan pembelajaran sepenuhnya melalui fasilitas web. Penyelenggaraan e-learning adalah sebagai suplemen atau komplemen terhadap pembelajaran yang dilaksanakan secara regular di kelas dalam rangka meningkatkan kualitas pembelajaran.

\section{Evaluasi Pembelajaran PAI dengan e-learning}

Sutikno (2009, hal. mengungkapkan ciri-ciri pembelajaran lebih detail yang salah satunya adalah evaluasi, baik evaluasi proses maupun evaluasi produk. SMA Laboratorium Percotnohan UPI seringkali melakukan evaluasi pembelajaran maupun evaluasi produk. Hal tersebut dilakukan agar melihat keberhasilan dari kegiatan evaluasi tersebut. Berbagai persiapan dilakukan oleh SMA Laboratorium Percontohan UPI baik guru maupun pihak sekolah. Evaluasi proses dilakukan pada saat proses pembelajaran maupun akhir pembelajaran yang dilakukan oleh guru. Kegiatan akhir evaluasi PAI dilakukan hanya pada saat UTS dan UAS saja, tetapi teknik evaluasinya dilakukan dengan cara e-learning. Setelah melakukan evaluasi akhir, dengan $e$ learning, kita dapat melihat daftar siswa mana yang remedial mana yang tidak. Remedial dapat langsung menggunakan e-learning, baik itu proses remedialnya, maupun hasil remedialnya.

Evaluasi produk dilakukan oleh pihak sekolah dalam hal ini wakasek kurikulum pada setiap akhir semester. Produk yang di evaluasi adalah media pembelajan e-learning itu sendiri. Dengan evalausi tersebut maka media pembelajaran e-learning terus digunakan untuk keberlangsungan proses pembelajaran di SMA Laboratorium Percontohan UPI. Maka media pembelajaran e-learning digunakan siswa agar memberikan petunjuk yang terarah bagi perkembangan hasil evaluasi belajar. (Sagala, 2006, hal. 156). Senada dengan Hartanto (2016, hal. 24). bahwa strategi e-learning melibatkan empat tahap yaitu analisis, perencanaan, pelaksanaan dan evaluasi. Evaluasi, setelah melaksanakan rencana penerapan e-learning, selanjutnya menilai keberhasilan program dan produk.

Hartanto (2016, hal. 23) dalam pengembangan suatu aplikasi e-learning bahwa harus memperhatikan teknik evaluasi kemajuan peserta didik dan penyimpanan data kemajuan peserta didik. Keberadaan e-learning di SMA Laboratorum Percontohan UPI sangat berarti ketika proses penilaian, karena $e$ learning mempunyai sistem otomatis tersendiri. Hal tersebut dapat mempermudah guru PAI untuk melihat kemajuan peserta didik dan penyimpanan data kemajuan peserta didik. Dalam e-learning, evaluasi dapat dipakai ketika satu sub bab materi selesai dipelajari oleh siswa. Sistem $e$ learning dapat mengagalkan siswa untuk melanjutkan materi selajutnya apabila 
tidak mengerjakan soal yang terdapat pada setiap sub bab materi.

Teknik penilaian dalam menggunakan media pembelajaran elearning di SMA Laboratorium Percontohan UPI tergantung dengan kompetensinya. Yang dapat dilakukan evaluasi ppada media pembelajaran $e$ learning adalaha kompetensi pengetahuan. Kompetensi sikap dan keterampilan dapat dilakukan secara langsung. Menurut Yuni(2017, hal. 33)bahwa Learning Management System memiliki beberapa ciri, di antaranya manajemen isi pelajaran, manajemen proses pembelajaran, evaluasi dan ujian yang dilakukan secara online yang mempunyai banyak teknik evaluasi, serta administrasi mata pelajaran, chatting, dan diskusi. Maka Learning Management System tidak mampu memperhatikan secara langsung terkait dengan prilaku yang peserta didik lakukan.

Dalam Undang-undang Nomor 14 Tahun 2005 tentang Guru dan Dosen seorang guru harus memenuhi empat kompetensi guru, salah satunya adalah kompetensi pedagogik. Kompetensi pedagogik yaitu kemampuan mengelola pembelajaran peserta didik yang meliputi pemahaman terhadap peserta didik, pengembangan potensi yang dimiliki peserta didik, perencanaan dan pelaksanaan pembelajaran, serta pengevaluasian hasil belajar. Upaya untuk meningkatkan kompetensi pedagogik pendidik maka guru SMA Laboratorium Percontohan UPI melakukan evaluasi dengan menuliskan kendala dan solusi yang telah terjadi pada saat pembelajaran maupun evaluasi pembelajaran. Pelaksanaannya dilakukan pada media pembelajaran $e$ learning yang terdapat form untuk menuliskan evaluasi tersebut. Maka dengan itu, guru akan melihat sejarah megajar guru pada setiap pembelajarannya.

\section{Hasil Proses Pembelajaran PAI dengan e-learning}

Dalam Undang-undang Nomor 14 Tahun 2005 tentang Undang-undang Guru dan Dosen (UUGD) bahwa kompetensi profesional seorang guru adalah seperangkat kemampuan yang harus dimiliki guru agar ia dapat melaksanakan tugas mengajarnya dengan berhasil. Kompetensi tersebut akan menentukan keberhasilan siswa dalam proses pembelajaran. Guru SMA Laboratorium Percontohan UPI sebagian besar dapat dikatakan sudah berkompetensi profesional. Guru menggunakan media pembelajaran $e$ learning adalah salah satu bentuk penilaian yang dilakukan sekolah dalam menentukan kompetensi profesional. Upaya tersebut upaya sekolah dalam mengoptimalkan penggunaan media pembelajran e-learning. Maka keberhasilan siswa di SMA Laboratorium Percontohan UPI akan terjadi.

Mudhoffir dalam (Munadi, 2010, hal. 37) menyebutkan bahwa sumber belajar pada hakikatnya merupakan komponen sistem instruksional, yang meliputi pesan, orang, bahan, teknik, dan lingkungan yang mana hal itu dapat mempengaruhi hasil belajar siswa. Tidak semua siswa akan mendapatkan sumber belajar yang seharusnya mereka dapatkan. Semisal ketika siswa ada yang tidak memiliki buku sebagai sumber belajar, maka siswa tersebut akan sulit 


\section{Rijki Ramdani, Munawar Rahmat, Agus Fakhruddin}

untuk melakukan pembelajaran secara mandiri. Media pembelajaran e-learning sebagai solusi terhadap permasalahan tersebut. SMA Laboratorium Percontohan UPI sudah mengevaluasi terhadap pengaruh yang terjadi pada kompetensi pengetahuan siswa dan hasilnya bahwa media pembelajaran elearning mampu mempengaruhi hasil belajar siswa. Menurut Rohmah (2016, hal. 12)bahwa E-learning dapat membawa suasana baru dalam ragam pengembangan pembelajaran. Pemanfaatan e-learning dengan baik dapat meningkatkan hasil pembelajaran dengan maksimal.

Hartanto (2016, hal. 28) bahwa Learning Management System Efront juga berperan sebagai media berbagi, berdiskusi, dan belajar bersama dengan memanfaatkan berbagai fitur dan fasilitas pendukung yang ada. Dengan penerapan pembelajaran ini tentu melibatkan keaktifan dari kedua belah pihak, baik guru maupun peserta didik itu sendiri yang diharapkan dapat meningkatkan minat belajar peserta didik serta memberikan dapak positif pada hasil belajar peserta didik. Pemilihan platform e-learning harus memperhatikan ciri dan kualitas dari LMS yang akan digunakan. Efront merupakan sebuah platform open source atau sering disebut dengan LMS. Efront dirancang khusus sebagai aplikasi yang dapat digunakan untuk pembelajaran, mulai dari membuat isi, membuat tes, pengelolaan tugas, laporan, chat, forum, dan lainnya. Terkadang pemilihan aplikasi LMS pun akan berpengaruh terhadap hasil belajar siswa, karena setiap aplikasi mempunyai fitur yang berbeda-beda.
Fitur-fitur tersebut mempunyai fungsinya masing-masing dan akan dibutuhkan oleh siswa maupun guru.

\section{PENUTUP}

Berdasarkan hasil dan pengolahan data, dapat dikemukakan simpulan sebagai berikut:

Perencanaan pembelajaran PAI dengan media pembelajaran e-learning yang diterapkan di SMA Laboratorium Percontohan UPI dimulai dengan berbagai latar belakang. Media pembelajaran e-learning digunakan karena bersifat fleksibel, tidak terbatas oleh waktu dan akan memudahkan pembelajaran baik siswa maupun guru, hal tersebut atas kebutuhan guru dan siswa untuk proses pembelajaran yang akan memudahkan dalam pelaksanaan pembelajaran. Upaya tersebut untuk menciptakan pembelajaran yang efektif. Kemudian perencanaan perangkat ajar yang direncanakan sekolah dalam hal ini guru sudah dilakukan treatment oleh sekolah yang bertujuan untuk menyesuaikan perangkat ajar dengan media pembelajaran e-learning. Secara umum berada pada kategori baik.

Proses pembelajaran PAI dengan media pembelajaran e-learning di SMA Laboratorium Percontohan UPI dapat dikatakan sudah baik. Penerapan media pembelajaran e-learning dapat dilakukan dengan tiga cara, dan di SMA Laboratorium sudah pernah semuanya dan tergantung terhadap materi pembelajaran. Maka media pembelajaran e-learning bukan sebagai pengganti pembelajaran konvensional, melainkan sebagai alat bantu pembelajaran. Kemudian media pembelajaran e-learning perlu adanya 
fasilitator yang mengarahkan siswa, dalam hal ini guru, meskipun media pembelajaran e-learning seringkali menggunakan strategi student centre learning. Tetapi dengan media pembelajaran e-learning akan membantu guru pada saat guru tidak dapat hadir ke kelas. Pembelajaran tetap bisa berlangsung dengan media pembelajaran e-learning.

Evaluasi pembelajaran dengan media pembelajaran e-learning di SMA Laboratorium Percontohan UPI dapat dikatakan sudah baik, seperti fitur yang terdapat pada e-learning terutama aplikasi LMS Efront salah satunya adalah evaluasi pelajaran. Evaluasi pelajaran tersebut dimanfaatkan oleh SMA Laboratorium Percontohan UPI. Evaluasi yang dilakukan berupa evaluasi produk dan evaluasi pembelajaran.

Hasil proses pembelajaran PAI dengan menggunakan media pembelajaran e-learning di SMA Laboratorium Percontohan UPI terlihat adanya peningkatan sesuai dengan hasil observasi, peningkatan tersebut pada kompetensi pengetahuan, sikap dan keterampilan siswa, juga peningkatan terjadi pada keaktifan belajar siswa. Namun yang terlihat secara jelas adalah peningkatan pada kompetensi pengetahuan saja. Kompetensi sikap dan keterampilan sedikit kemungkinan yang dipengaruhi oleh media pembelajaran e-learning. Tetapi hasil belajar siswa pada sikap maupun keterampilan dapat dilakukan dengan secara langsung oleh guru di kelas. Nilai yang dihasilkan oleh siswa sangat variatif tergantung pada kemampuan mereka masing-masing.
Hal tersebut tidak lepas pada upaya guru dalam proses pembelajaran. Keberhasilan siswa terhadap pembelajaran sangat ditentukan juga dengan kompetensi profesional guru. Guru PAI di SMA Laboratorium Percontohan UPI dapat dikatakan sebagai guru profesional dengan memamfaatkan teknologi sebagai proses pembelajaran.

\section{REFERENSI}

Afdal, Z. (2012). Penerapan Pembelajaran E-learning dengan Aplikasi Moodle terbadap Sikap Belajar dan Penguasaan Konsep: Studi Eksperimen pada Mahasiswa FKIP UIR Pekanbaru - Riau. Dipetik 03 20, 2018, dari http:/ / repository.upi.edu/tesis view.php?no_tesis $=2008$

Asyhar, R. (2012). Kreatif Mengembangkan Media Pembelajaran. Jakarta: Gaung Persada Press.

Effendi, E. Z. (2005). E-Learning Konsep dan Aplikasi. Yogyakarta: ANDI.

Fathan. (2016). Hadits Sifat Kreatif. Dipetik Maret 26, 2018, dari Dakwah Islami: http://www.dakwahislami.xyz/ 2016/07/hadits-sifatkreatif.html

Hamalik, O. (2010). Kurikulum dan Pembelajaran. Jakarta: Bumi Aksara.

Hamdani. (2003). Contextual Teaching and Learning (CTL) pada pembelajaran PAI. NIZAMIA Jurnal Pendidikan dan Pemikiran Islam. 
Hamdani. (2003). Contextual Teaching and Learning (CTL) pada pembelajaran PAI. NIZAMIA Jurnal Pendidikan dan Pemikiran Islam, XI(1), 10-19. DOI 10.21093/di.v11i1.49.

Hamid, A. (2015). Efektifitas Implementasi LMS (Learning Management System) Efront Terbadap Minat Dan Hasil Belajar Pada Mata Pelajaran Pemrograman Web di SMK Negeri 8 Semarang. Semarang: Skripsi Kurikulum dan Teknologi Pendidikan, Fakultas Ilmu Pendidikan, Universitas Negeri Semarang.

Hartanto, W. (2016). Penggunaan ELearning Sebagai Media Pembelajaran. Jurnal Pendidikan Ekonomi: Jurnal Ilmiah Ilmu Pendidikan, Ilmu Ekonomi dan Ilmu Sosial, 16 - 31.

Hartanto, W. (2016). Penggunaan ELearning Sebagai Media Pembelajaran. Jurnal Pendidikan Ekonomi: Jurnal Ilmiah Ilmu Pendidikan, Ilmu Ekonomi dan Ilmu Sosial, X(1), 16 - 31.

Kusnandar. (2011). Guru Profesional. Jakarta: Rajawali Press.

Lena. (2009). Model Pembelajaran E-

Learning Melalui Homepage Sebagai Media Pembelajaran Sehingga Diharapkan Dapat Meningkatkan Minat Dan Kreativitas Siswa. Jurnal ABMAS Media Komunikasi dan Infromasi Pengabdian Kepada Masyarakat, 414-875.

Lena. (2009). Model Pembelajaran ELearning Melalui Homepage Sebagai Media Pembelajaran Sehingga Diharapkan Dapat
Meningkatkan Minat Dan

Kreativitas Siswa. Jurnal ABMAS Media Komunikasi dan Infromasi Pengabdian Kepada Masyarakat, IX(9), 414-875.

Mahnun, N. (2012). Media Pembelajaran (Kajian terhadap Langkah-langkah Pemilihan Media dan Implementasinya dalam Pembelajaran). Jurnal Pemikiran Islam, XXXVII(1), 27-33. ISSN 0853-1161.

Moleong, L. J. (2012). Metode Penelitian Kualitatif. Bandung: Remaja Rosda Karya.

Munadi, Y. (2010). Media Pembelajaran (Sebuah Pendekatan Baru). Jakarta: Gaung Persada (GP) Press.

Munir. (2008). Kurikulum Berbasis Teknologi Informasi dan Komunukasi. Bandung: CV Alfabeta.

Nazir, M. (1999). Metode Penelitian . Jakarta: Ghalia Indonesia.

Prawiradilaga, D., \& Siregar, E. (2008). Mozaik Teknologi Pendidikan. Jakarta: Kencana Prenada Media Group.

Riajluttaqwa, H. (2012). Penggunaan Metode Amsal Qurani dalam Pembelajaran Pendidikan Agama Islam di Sekolah. Jurnal Tarbawi, I(2), 125-134.

Rohaya. (2009). Minat Belajar Pendidikan Agama Islam Hubungannya dengan Ibadah Shalat Wajib. Bandung: Fakultas Tarbiyah dan Keguruan UIN Sunan Gunung Djati.

Rohmah. (2016). Konsep E-Learning Dan Aplikasinya Pada Lembaga 
Pendidikan Islam. Jakarta: AnNur.

Rokhman, N., Sardiman, \& Pramandanu, R. (2015). Pengembangan Media Blog Sejarah untuk Pembelajaran Sejarah di SMA. Istoria: Jurnal Pendidikan dan Ilmu Sejarah, 5470.

Rokhman, N., Sardiman, \& Pramandanu, R. (2015). Pengembangan Media Blog Sejarah untuk Pembelajaran Sejarah di SMA. Istoria: Jurnal Pendidikan dan Ilmu Sejarah, XI(1), 54-70.

Sagala, S. (2006). Konsep dan Makna Pembelajaran. Bandung: Pustaka Alfabeta.

Saroni, M. (2011). Personal Branding Guru: Meningkatkan Kualitas dan Profesionalitas Guru. Yogyakarta: Ar-Ruzz Media.

Setiawan, W. (2006). Pembelajaran Berbasis ICT :Model ELearning Menggunakan Opensource Moodle. Mimbar Pendidikan Jurnal Pendidikan, IV(4), 376-875.

Shihab, Q. (2006). Tafsir AlMisbah. Yogyakarta: Lentera Hati.

Sudrajat, A. (2008, Januari 12). Konsep Media Pembelajaran. Dipetik Desember 30, 2012, dari akhmadsudrajat.wordpress.com http://akhmadsudrajat.wordpr ess.com/2008/01/12/konsepmedia-pembelajaran/

Sutikno, M. S. (2009). Belajar dan Pembelajaran. Bandung: Prospect.

Syah, M. (2000). Psikologi Pendidikan dengan Pendekatan Baru. Bandung: PT Remaja Rosda Karya.

Syah, M. (2016). Psikologi Pendidikan dengan Pendekatan Baru. Bandung: PT Remaja Rosda Karya.

Welsh, E. T., Wanberg, C., Brown, K., \& Simmering, M. (2003). Elearning: Emerging Uses, Empirical Result, and Future Directions. International Journal of Training and Development, VII(4), 245-258. DOI $10.1046 /$ j.13603736.2003.00184.x.

Yazdi, M. (2012). E-learning sebagai Media Pembelajaran Interaktif Berbasis Teknologi Informasi. Jurnal Ilmiah Foristek, II(2), 143152.

Yunis, R., \& Telaumbanua, K. (2017). Pengembangan E-Learning Berbasiskan LMS untuk Sekolah, Studi Kasus SMA/SMK di Sumatera Utara. Jurnal Nasional Teknik Elektro dan Teknologi Infromasi, 32-36. 